\title{
Technical Guidance 21st Century Learning Application to Improve the Pedagogic and Professional Competence of Elementary School Teacher
}

\author{
Dyoty Auliya Vilda Ghasya a), and Kartono \\ Program Studi S1 PGSD FKIP Universitas Tanjungpura, Pontianak, Indonesia \\ a)Corresponding Author: dyoty@fkip.untan.ac.id
}

\begin{abstract}
At this time the 21st century is known by all audiences as the era of knowledge which is used as a foundation in various aspects of the wheel of life with the characteristic of providing information anywhere and anytime and increasing the interaction of world citizens either directly or indirectly. Talking about 21st century skills, education today should not only be about knowledge of the subjects being taught but also lead to leadership, responsibility, problem solving, analytical thinking, adaptability, communication, initiative, self-direction, creativity, cross-cultural skills, and work. same. Through this PKM activity bridges teachers to have 21st century skills in the form of (1) Critical Thinking Skills; (2) Ability to Solve Problems; (3) Communication and Collaboration; (4) Creativity and Innovation; (5) Information, Communication, and Technology Media Literacy. Teachers as people who daily wrestle with the world of education and have direct contact with students in schools must be able to change their teaching style according to the needs of the 21 st century.
\end{abstract}

Key words: Learning, pedagogic, professional, teacher, elementary school

\section{INTRODUCTION}

At this time the 21 st century is known by all audiences as an era of knowledge that is used as a basis in various aspects of the wheel of life with the characteristic of providing information anywhere and anytime and increasing the interaction of world citizens both directly and indirectly (Aditya, 2019). . Likewise, the 21st century education aspect currently prioritizes the first, skills in terms of learning and innovation including creativity, critical thinking and problem solving, communication and collaboration, second skills in terms of information, media and technology including information literacy, media literacy, information technology literacy, and the third life and career skills include being flexible and able to adapt, having initiative and selfdirection, having social and cross-cultural skills as well as being productive and accountable.

Talking about 21 st century skills, today's education should not only be about knowledge of the subjects taught but also lead to leadership, responsibility, problem solving, analytical thinking, adaptability, communication, initiative, self-direction, creativity, cross-cultural skills, and work. the same (Andrian and Rusman, 2021). Regarding education in the 21st century in Indonesia, it has been regulated in the Regulation of the Minister of Education and Culture number 22 of 2016 concerning the standard of the primary and secondary education process. Meanwhile, UNESCO has set four pillars of education to welcome the 21st century, namely learning to how (learning to know), learning to do (learning to do), learning to be (learning to actualize oneself as an independent individual with personality), learning to live together ( learn to live together).

Based on the explanation of the direction of education in the 21st century, elementary school teachers are required to have mature knowledge about the direction of 21st century learning because elementary school teachers are educators for students who have an age range of 7 to 12 years. In this age range of students, teachers can easily instill skills that must be mastered by students in the 21st century, even elementary school age students have the ability to continuously progress from spontaneous movements and reflexes to acquired habits towards intelligence. Elementary school students are also active beings and excellent imitators and are in 
the stages of concrete pre-operational cognitive development. Therefore, elementary school teachers should not provide learning experiences and incorrect information to students during the teaching and learning process (Latifah, 2017).

Through initial field observations conducted by the Community Service (PKM) proposing team at partner elementary schools, namely SDN 08 Sungai Kakap, information was obtained that teachers still need guidance to improve pedagogic and professional competencies, especially regarding the direction of learning in the 21st century for elementary school level. In addition, the teacher at the partner primary school revealed that they still need direction on the challenges of teaching in the 21st century which include teaching in a culturally diverse society with multilingual competence, teaching to construct meaning (concepts), teaching for active learning, teaching and technology, teaching with a new view of ability, teaching and choice, teaching and accountability (Baroya 2018).

Seeing these problems, the team proposing Community Service (PKM) plans to implement "Technical Guidance for the Implementation of 21st Century Learning to Improve Pedagogic and Professional Competence of Elementary School Teachers". Activities in these technical guidance activities will later provide teachers with useful training in improving teacher competence with the materials provided include (1) teachers and global awareness, (2) holistic, contextual and futuristic learning principles, (3) the use of technology information and communication in 21st century learning, (4) designing and assessing 21st century learning, (5) teaching in culturally diverse schools with multilingual competence, and (6) teaching to construct meaning.

\section{METHOD}

The service team carried out activities at the Sungai Kakap Public Elementary School 08, which was located on JI. Raya KM 18, Sungai Kakap District, Kubu Raya Regency, West Kalimantan. The service team and the 08 Sungai Kakap State Elementary School represented by the Principal agreed to carry out the service for 2 days of activity. This PKM activity carries the title "Technical Guidance for the Application of 21st Century Learning to Improve Pedagogic and Professional Competence of Elementary School Teachers". The location chosen to carry out this PKM activity is SDN 08 Sungai Kakap which is located on Jl. Raya KM 18, Sungai Kakap District, Kubu Raya Regency, West Kalimantan. The steps that have been taken by the research team include:

1. Preparation stage. The preparation stage is the initial stage before the implementation of the PKM. At this stage, there are several things that will be done, including internal coordination, determining and participating in technical guidance, making PKM instruments, making technical guidance modules, coordinating with partners, determining training locations and so on.

2. Implementation stage. The stages of implementing technical guidance that will be carried out by the service team are as follows.

a) Exposure to the 21st century educational paradigm.

b) Presentation of sub-materials on the implementation or application of 21 st century learning which includes teachers and global awareness, holistic, contextual and futuristic learning principles, utilization of information and communication technology in 21st century learning, designing and assessing 21st century learning, teaching in schools that have diverse cultures with multilingual competence, teaching to construct meaning.

c) Assistance to teachers in designing 21st century learning strategies for elementary school level.

d) Assignment and practice. At the end of the material, the teacher will be given practical assignments according to the material that has been presented to explore the extent of absorption and understanding of the material that has been delivered. At this stage, the service team will accompany, assist and direct and provide solutions if problems arise during the assignment period. 
e) Reflection and closing of the PKM program. At the end of the activity, the teacher and the service team reflected on the results of the training and the teachers also provided an evaluation of this technical guidance training.

3. Evaluation of activities. The service team will evaluate the results of the teachers' practical assignments. These results will be used as an illustration of the success of the material that has been presented. In addition, the service team will pay close attention to the process of teacher participation in these activities.

\section{RESULTS}

The consideration of the service team in choosing the location was that the service team first conducted an initial survey to SDN 08 Sungai Kakap after that the service team obtained information directly from the principal that had never received technical guidance on the 21st Century educational paradigm then the teachers at SDN 08 Sungai Kakap also hopes that there will be training to support distance learning during the COVID-19 pandemic, secondly considering safety and health because at this time the COVID-19 pandemic, the service team finally chose a location to carry out PKM that could still be accessed quickly and easily. easy because the implementation of the activity lasted for two days. In addition, the service team and participants also carry out activities by following health protocols such as measuring body temperature, wearing masks during activities, maintaining distance, preparing hand sanitizers, preparing hand washing soap and so on.

Through this PKM activity, teachers are bridging to have 21st century skills in the form of (1) Critical Thinking Skills; (2) Problem Solving Ability; (3) Communication and Collaboration; (4) Creativity and Innovation; (5) Information, Communication, and Technology Media Literacy. Teachers as people who daily struggle with the world of education and are in direct contact with students at school must be able to change their teaching style according to needs according to the demands of the 21st century (Syahputra, 2018).

In this 21st century skill, there are several things that need to be developed, as stated in Permendikbud number 21 of 2016 which states that Graduate Competency Standards in 2013 curriculum learning are based on 21st Century competencies, these competencies contain soft skill competencies. Famewok partnership of 21st Century Skills, defines it as "The 4C Skills." Namely Critical Thinking, Communicaion, Collaboration, and Creativity (Susanti and Arista, 2019). That is, the needs of life in the 21st century in the world of education require a shift in educational goals by preparing students to face an increasingly stringent world in the struggle of thought and creativity. In this case, mastering soft skills as mentioned above will be more useful than just mastering hard skills (Trisnawati and Sari, 2019).

\section{DISCUSSION}

These 21st century skills are relevant to the four pillars of education which include learning to know, learning to do, learning to be and learning to live together. Learning to Know means that education should direct students to have broad knowledge. Mastery of the material is a very important thing that must be pursued by students (Rahmi and Suparman, 2019). Therefore, students must have great motivation to always learn to deepen knowledge that always develops from time to time (Nafrin and Hudaidah, 2021).

However, the process of teaching and learning activities at schools which were previously carried out directly by means of face-to-face meetings (PTM) between teachers and other students, has now turned into distance learning since the Covid-19 outbreak. On March 2, 2020, for the first time, the government announced two positive cases of Corona Virus Disease 2019 (covid-19) in Indonesia. Corona Virus Disease 2019 is a large family of viruses that can cause disease in animals and humans. In humans, corona viruses are known to cause respiratory tract infections ranging from the common cold to more severe diseases such as Middle East Respiratory Syndrome (MERS) and Severe Acute Respiratory Syndrome (SARS). While the 
latest corona virus is the one that causes covid-19, which is an infectious disease caused by the newly discovered corona virus (Sukur et al, 2020).

This new virus and disease was not known before the outbreak started in Wuhan, China in December 2019. This covid-19 is now a pandemic that affects all countries in the world. The Covid-19 virus can cause various symptoms in its sufferer. With the outbreak of the COVID-19 pandemic, teachers, students, and parents or guardians of students in elementary schools have felt a significant change in the implementation of learning, namely distance learning. Distance learning in elementary school can certainly run well if it is carried out through parental guidance. With distance learning, students are expected to have the opportunity to learn anywhere and anytime. Distance learning is an innovation in education to provide varied learning resources.

This of course really requires great motivation from students because they are required to be fully biased in carrying out the practice of Learning to do. Learning to do, namely education should be able to encourage students to continue to work. Education is not enough to provide extensive knowledge, but the knowledge and skills possessed by students must be actualized into a work that can reflect something meaningful in their lives. Leaning to be, that is, through education, students should be able to recognize their identity armed with the mastery of the knowledge and skills they have acquired. Knowing one's identity means knowing one's personal needs as an individual or as part of society, namely being able to behave according to the norms and rules that apply in society. Learn to live together, students should be accustomed to live cooperatively in a learning environment (Ismail and Ismail, 2018).

Teachers must understand the characteristics of 21 st century learning in order to prepare their students to be able to compete at the global stage. Competition that occurs in the 21st century has a very broad scope to the international world. This is due to the development of technology and communication that knows no space and time (Siahaan, 2020). Therefore, teachers must equip themselves with the ability to master technology and information as an effort to balance the entry of technological equipment used in learning process activities, especially at this time distance learning is taking place during the COVID-19 pandemic (Khasanah, et al, 2020).

The main task of the teacher in 21st century learning is as a facilitator who is required to be able to prepare learning materials well in accordance with the demands of the 21st century, namely ICT-based learning. With the use of technology, students can easily access the information they get from the internet, therefore in the learning process elements of higherorder thinking must be included. In 21 st century learning, not only students are required to become human learners, but teachers must also become human learners as well. This is because the life of the 21st century moves very quickly, allowing teachers and students to compete in mastering information (Pujilestari, 2020).

In facing the challenges of 21st century learning, teachers must prepare themselves by (a) Being human learners, teachers are required to be able to keep pace with the changing times that are so fast by continuing to learn what is needed, teachers must be diligent in discussing, reading and participating in discussion forums. (b) Mastering technology, the 21st century is an era that cannot be separated from technology so that teachers absolutely master technology. If the teacher does not master technology, then how can he convey the material and direct his students in the learning process. (c) Creative and innovative, teachers are directed to always be creative and innovative. (d) Learner-centered learning, teachers must be able to condition students to be active in the classroom and not only depend on teachers in utilizing learning resources, they must be able to explore information independently by utilizing various existing media, while the position of the teacher there is a facilitator who guides and accompanies students in the learning process. (e) Reflective, rapid changes require teachers to evaluate the learning activities that have been carried out, so that teachers can develop strategies to carry out the learning process in a different atmosphere so that students remain interested in participating in the learning process.

The implementation of the PKM activities mentioned above went very well and according to the planned schedule. The teachers of SDN 08 Sungai Kakap were very enthusiastic about 
receiving the material because so far they had never received technical guidance on the 21st Century learning paradigm. In addition, teachers also received technical guidance on Distance Learning in Elementary Schools during the COVID-19 pandemic. 19. Through this PKM activity, the service team and teachers at SDN 08 Sungai Kakap were also able to conduct discussions related to the rapid development of the world of education in elementary schools in terms of learning and non-learning. The real results of this PKM implementation are that the teachers of SDN 08 Sungai Kakap are able to create Google Forms, Google Classrooms, You Tube accounts, and various learning media such as e-videos and so on.

\section{CONCLUSIONS AND RECOMMENDATIONS}

The conclusions from the implementation of service activities that will be carried out by the service team are as follows. Elementary school teachers are required to have mature knowledge about the 21st century learning paradigm this is because elementary school teachers are educators for students who have an age range of 7 to 12 years. In this age range, teachers can easily in still skills that must be mastered by students in the 21 st century. Teachers should also remember that elementary school students are excellent imitators and are in the concrete preoperational stages of cognitive development. Therefore, elementary school teachers should not provide learning experiences and incorrect information to students during the teaching and learning process. Teachers must be able to design attractive learning strategies to face the challenges of 21 st century education, especially at this time students are conducting distance learning with teachers due to the COVID-19 pandemic so teachers are required to master technology to deliver various kinds of learning materials.

\section{ACKNOWLEDGMENTS}

Special thanks are addressed to the Faculty of Teacher Training and Education, Tanjungpura University, Pontianak, West Kalimantan.

\section{REFERENCES}

Aditiya, N. (2021). Pengembangan. Bahan. Ajar. Berbasis. Kearifan. Lokal Bangka Pada. Subtema.

Bersyukur. Atas. Keberagaman. Di. Kelas. IV. SD (Doctoral dissertation, UIN Raden Fatah Palembang).

Andrian, Y., \& Rusman, R. (2019). Implementasi pembelajaran abad 21 dalam kurikulum 2013. Jurnal Penelitian IImu Pendidikan, 12(1), 14-23.

Baroya, E. H. (2018). Strategi pembelajaran abad 21. As-Salam: Jurnal Ilmiah Ilmu-Ilmu Keislaman, 1(1), 101-115.

Ismail, R. A. R., \& Ismail, D. (2018). Aplikasi 'Konsep 4C'pembelajaran abad ke-21 dalam kalangan guru pelatih pengajian agama Institut Pendidikan guru kampus Dato'Razali Ismail. Asian People Journal (APJ), 1(1), 45-65.

Khasanah, D. R. A. U., Pramudibyanto, H., \& Widuroyekti, B. (2020). Pendidikan dalam masa pandemi covid-19. Jurnal Sinestesia, 10(1), 41-48.

Latifah, U. (2017). Aspek perkembangan pada anak Sekolah Dasar: Masalah dan perkembangannya. Academica: Journal of Multidisciplinary Studies, 1(2), 185-196.

Nafrin, I. A., \& Hudaidah, H. (2021). Perkembangan Pendidikan Indonesia di Masa Pandemi Covid-19. Edukatif: Jurnal IImu Pendidikan, 3(2), 456-462.

Pujilestari, Y. (2020). Dampak positif pembelajaran online dalam sistem pendidikan Indonesia pasca pandemi covid-19. Adalah, 4(1).

Rahmi, A., \& Suparman, S. (2019). Analisis kebutuhan modul dengan pendekatan CTL untuk meningkatkan motivasi belajar dan keterampilan $4 c$ pada peserta didik. Prosiding Sendika, $5(1)$.

Siahaan, M. (2020). Dampak pandemi Covid-19 terhadap dunia pendidikan. Dampak Pandemi Covid-19 Terhadap Dunia Pendidikan, 20(2). 
Sukur, M. H. 2020. "Penanganan Kesehatan Di Masa Pandemi Covid-19 Dalam Perspektif Hukum Kesehatan". Journal Incio Legis. 1(1).

Susanti, E., \& Arista, A. (2019, November). Analisa Tingkat Pengetahuan Guru terhadap Kompetensi 4C. In Prosiding Seminar Nasional IImu Sosial Dan Teknologi (SNISTEK), September (pp. 73-78).

Syahputra, E. (2018, March). Pembelajaran abad 21 dan penerapannya di Indonesia. In Prosiding Seminar Nasional SINASTEKMAPAN (Vol. 1, No. 1, pp. 1277-1283).

Trisnawati, W. W., \& Sari, A. K. (2019). Integrasi Keterampilan Abad 21 Dalam Modul Sociolinguistics: Keterampilan 4C (Collaboration, Communication, Critical Thinking, Dan Creativity). Jurnal Muara Pendidikan, 4(2), 455-466. 


\section{APPENDIX}

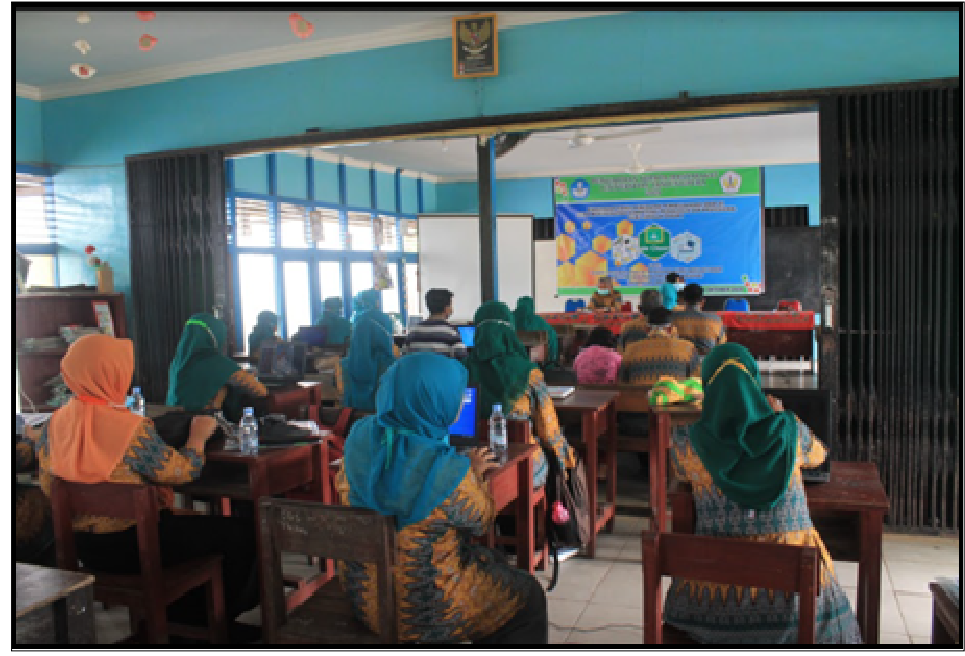

Figure 1. Technical guidance

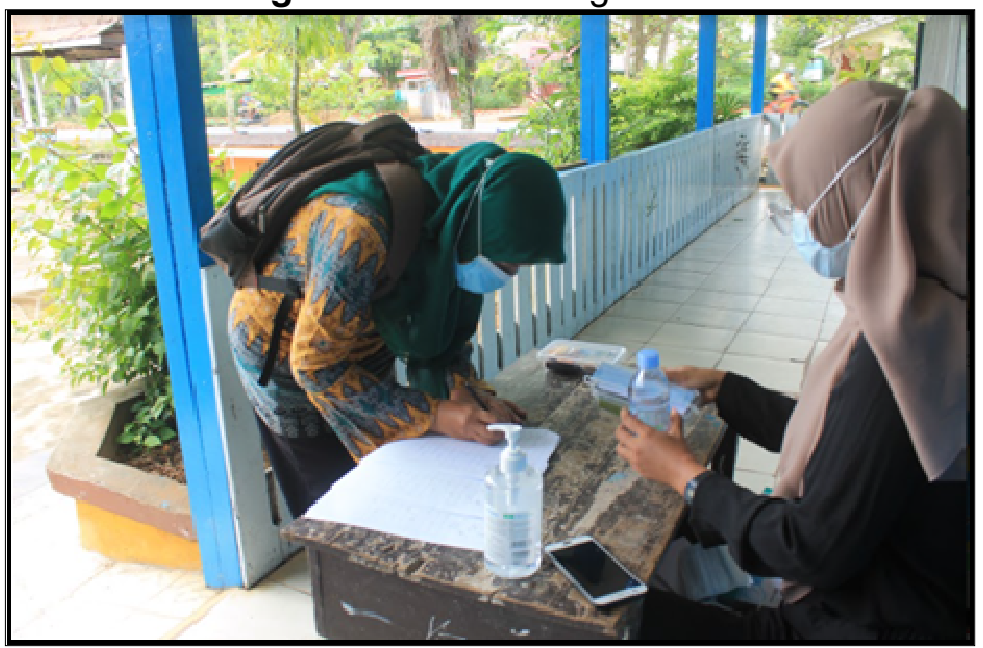

Figure 2. Participant registration 